\title{
A Neurologist's Hard Day's Work: Impact of Inpatient Neurology Consultation in a Tertiary Hospital
}

\author{
O Dia-a-dia de um Neurologista Hospitalar: Impacto das \\ Consultas Internas de Neurologia num Hospital Terciário
}

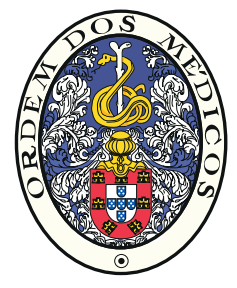

\author{
Helena ROCHA $\bigotimes^{1,2}$, Ana MONTEIRO ${ }^{1,2}$, Tiago GOMES ${ }^{1,2}$, Miguel GRILO ${ }^{1,2}$, Marta CARVALHO ${ }^{1,2}$ \\ Acta Med Port 2016 Jan;29(1):46-51
}

\section{ABSTRACT}

Introduction: Consultation of hospitalized patients under the responsibility of other specialties is a very demanding work. However, it is often under-recognized and poorly documented. The aim of the present study was to assess the burden of the inpatient neurology consultation in a Portuguese hospital and to evaluate the performance of our Neurology department regarding this issue.

Material and Methods: A retrospective study was conducted during 2013, reviewing clinical and demographic data.

Results: Over one year, the neurologists of our department evaluated 632 inpatients. The commonest reasons for consultation were altered mental state/behavior, focal neurological deficit and seizures. Requests came mainly from medical departments but also from Intermediate and Intensive Care Units. Neurologists suggested further investigation in almost one half of patients and management changes in a similar proportion of patients. A new diagnosis could be established in $63 \%$ of cases and the most frequent diagnosis were neurological manifestations of systemic disorders, epilepsy and cerebrovascular disease. Our intervention had impact on the care of $68 \%$ of patients.

Discussion and Conclusion: Different studies in the literature support our findings and highlight the economic and patient care benefits of this activity. Our results suggest that neurological inpatient observation generates useful interventions for the clinical management of these patients.

Keywords: Inpatients; Neurology; Quality of Health Care; Referral and Consultation.

\section{RESUMO}

Introdução: A consulta de neurologia realizada a doentes hospitalizados sob a responsabilidade de outras especialidades é um trabalho exigente mas muitas vezes sub-valorizado e pouco documentado. Este estudo pretendeu avaliar o impacto das consultas internas de neurologia num hospital português e, consequentemente, a performance do nosso Serviço no que diz respeito a esta matéria. Material e Métodos: Foi conduzido um estudo retrospetivo durante o ano de 2013 através da revisão de dados clínicos e demográficos.

Resultados: Ao longo de um ano, os neurologistas no nosso Serviço avaliaram 632 doentes internados. As principais razões para o pedido de consulta foram a alteração do estado mental/comportamental, défice neurológico focal e crises epiléticas. Os pedidos de avaliação provieram principalmente de serviços médicos mas também de Unidades de Cuidados Intensivos e Intermédios. Os neurologistas sugeriram investigação adicional em cerca de $50 \%$ dos doentes; alterações terapêuticas foram efetuadas numa proporção semelhante de doentes. No final da consulta foi possível estabelecer um novo diagnóstico em $63 \%$ dos casos, sendo os mais frequentes manifestação neurológica de doenças sistémicas, epilepsia e doença vascular cerebral. Tal intervenção teve impacto no cuidado de $68 \%$ dos doentes.

Discussão e Conclusão: Diferentes estudos na literatura suportam os nossos achados, enfatizando que esta atividade tem benefícios diretos no tratamento dos doentes e que é custo-efetiva. Os nossos resultados sugerem que a atividade de consultadoria interna da Neurologia resulta em intervenções úteis para a gestão clínica dos doentes internados.

Palavras-chave: Doentes Internados; Neurologia; Qualidade de Cuidados de Saúde; Referência e Consulta.

\section{INTRODUCTION}

In our Portuguese tertiary hospital, the working day of a neurologist is diverse and challenging. It takes place at the outpatient clinics, the wards and the emergency department (ED). Consultation of hospitalized patients under the responsibility of other specialties is a very demanding work, which implies great availability, strict knowledge of the patients as a whole and expertise in managing several and diverse comorbidities. The impact of this activity is poorly documented and only a few studies have focused exclusively on this subject. ${ }^{1-5}$

The aim of our work was to assess the burden of inpatient neurology consultation, in a Portuguese hospital, and to evaluate the performance of our department regarding this

1. Department of Neurology. Centro Hospitalar São João. Porto. Portugal.

2. Faculty of Medicine. University of Porto. Porto. Portugal.

$\triangle$ Autor correspondente: Helena Rocha. helen.roch@gmail.com

Recebido: 24 de abril de 2015 - Aceite: 02 de agosto de 2015 | Copyright @ Ordem dos Médicos 2016 specific activity.

\section{MATERIAL AND METHODS}

We performed a retrospective study of the referrals for neurology consultation of inpatients under the responsibility of other specialties, excluding the ED. The study was conducted from January to December 2013 in Centro Hospitalar São João, Porto, a tertiary and university teaching hospital with 1124 beds for a population of up to 3 million people.

Clinical records were reviewed and demographic and clinical data were obtained, namely: main reason for referral, previous history of neurological disease, department and 
priority of referral and whether the patient was evaluated by a neurology resident or consultant. Concerning priority, the referrals are usually classified as either 'urgent' or 'normal', requiring evaluation within 24 or 48 hours, respectively. Data regarding the diagnosis, suggested management, as well as patient destination after each observation was also collected. An evaluation was considered as having impact whenever a change in diagnosis and/or management (clinical investigation or therapeutic change) was suggested. SPSS Statistics version 20 (IBM, Armonk, NY, USA) was used to perform descriptive statistics. When appropriate, a chi-square test was also used.

The study was approved by the local Ethics Committee.

\section{RESULTS}

Over one year, the neurologists from our department evaluated 632 inpatients under the responsibility of other specialties, performing a total of 1232 consultations (including re-evaluations). Fifty-six percent of patients were men, and mean age was $64 \pm 17$ years old (range $14-98$ years).

The reasons for requiring a neurologist's opinion were diverse. The commonest were altered state of consciousness/behavior (21\%), focal neurological deficit $(18 \%)$, and seizures (17\%). Around one third $(37 \%)$ of inpatients already had a past history of neurological disease, which prompted per se $18 \%$ of evaluations. Other reasons are listed in Table 1.

One half of the referrals came from medical departments, the majority from Internal Medicine (20\%), Psychiatry $(6 \%)$ and Infectious Diseases (6\%). Twenty-eight percent of referrals were made by Intermediate and Intensive Care
Units (namely from cardiothoracic, neurointensive or general Intermediate/Intensive Care Units) and 22\% were from surgical departments.

Priority was considered 'urgent' by the requiring specialty in $30 \%$ of cases and 'normal' in $39 \%$. In $31 \%$ of referrals the priority was not documented, corresponding to requests made directly by phone call, mostly leading to consultation in the same day. For the cases with a known priority, the time from request to evaluation was fully accomplished in $84 \%$ of cases (data not available in $4 \%$ ). Consultants and residents independently assessed $35 \%$ and $55 \%$ of inpatients, respectively. Both residents and consultants performed $9 \%$ of consultations (there was unspecified data in $1 \%$ ).

In about one half of patients (49\%), further investigation was suggested, mostly imaging studies (12\%) and analytical tests (10\%). Occasionally, additional investigation was discouraged. In $48 \%$ of patients, specific therapeutic changes were made. General advices were offered in a similar proportion of patients $(47 \%)$, such as establishing goals concerning vascular risk factors control, defining ideal timings for interventions after an acute stroke or suggesting evaluation by other specialties - Table 2 .

After neurologic evaluation, a new diagnosis was established in $63 \%$ of cases.

This includes patients in whom the diagnosis was changed, a new diagnosis was made, or when the prior diagnosis was framed in a more specific neurological syndrome (i.e., the etiology of stroke in a patient with CADASIL, or the epileptic syndrome in a patient with seizures).

Neurological manifestations of a systemic disorder

Table 1 - Reasons for referral and new diagnoses after neurology consultation

\begin{tabular}{|c|c|c|c|c|c|}
\hline \multicolumn{3}{|l|}{ Reasons for referral } & \multicolumn{3}{|l|}{ New diagnoses established } \\
\hline & $\mathbf{n}$ & $\%$ & & $\mathbf{n}$ & $\%$ \\
\hline Altered mental state / behavior & 130 & 21 & $\begin{array}{l}\text { Neurological manifestation of systemic } \\
\text { disorder }\end{array}$ & 93 & 15 \\
\hline Focal neurological deficit & 112 & 18 & Epilepsy & 89 & 14 \\
\hline $\begin{array}{l}\text { Management of patients with previous neurological } \\
\text { diseases }\end{array}$ & 112 & 18 & Cerebrovascular disease & 78 & 12 \\
\hline Suspected seizure & 107 & 17 & Cognitive impairment/dementia & 47 & 7 \\
\hline Legal interdiction & 42 & 7 & Neuromuscular disorder & 33 & 5 \\
\hline Suspected extra-pyramidal/movement disorder & 24 & 4 & Movement disorder & 24 & 4 \\
\hline Headache & 20 & 3 & Headache & 10 & 2 \\
\hline Findings in ancillary diagnostic tests & 19 & 3 & CNS infection & 8 & 1 \\
\hline Brain death test & 13 & 2 & Other diagnosis & 15 & 3 \\
\hline Prognostic evaluation & 8 & 1 & & & \\
\hline Other causes & 21 & 3 & & & \\
\hline Unknown & 24 & 4 & & & \\
\hline Total & 632 & 100 & Total & 401 & 63 \\
\hline
\end{tabular}


Table 2 - Impact of neurology consultations

\begin{tabular}{lcc}
\hline & $\mathbf{n}$ & $\%$ \\
\hline Clinical investigation suggested & 310 & 49 \\
Change in treatment & 300 & 47 \\
General (non-pharmacological) advice & 299 & 47 \\
Overall impact on patient care & 430 & 68 \\
\hline
\end{tabular}

(15\%) such as toxic-metabolic encephalopathy, acute confusional syndrome/delirium and syncope/hypotension, were the most frequent. Epilepsy (14\%), cerebrovascular disease $(12 \%)$ and cognitive impairment/dementia $(7 \%)$ were the main neurological conditions diagnosed (Table 1). In $4 \%$ of patients the diagnosis was not specified.

An example of an immediate significant change in the diagnosis refers to a young man that was admitted because of complaints of unspecific lack of strength and a weird sensation in the lower limbs for the last three weeks; the neurological consultation found out a progressive paraparesis, ascending paresthesiae and a temporal association to a gastroenteritis; the diagnosis of Guillain-Barre syndrome was suspected - the spinal cord MRI already requested was cancelled and diagnosis was confirmed with cerebrospinal fluid study, conduction studies and electromyography; treatment with IV immunoglobulin was performed with significant clinical improvement. Other examples of a significant change in management after neurological evaluation were frequently made in cases referred to us for suspected dementia, in which our evaluation revealed, in fact, mimics such as major depression, delirium or secondary conditions - toxic-metabolic or severe vitamin deficits; in those cases the appropriate treatment was instituted and a prognosis established.

The proportion of diagnoses did not differ significantly between referring services. Patients with epilepsy and cerebrovascular diseases required more re-evaluations, especially those admitted to Intermediate or Intensive Care Units. A few cases (4\%) were taken over for neurology care at our department and an outpatient neurological re-

Table 3 - Brief summary of published studies addressing the impact of the hospital neurologist on the evaluation of inpatients under supervision

\begin{tabular}{|c|c|c|c|c|}
\hline Study & Country & $\begin{array}{c}\text { Number of } \\
\text { consultations/ period } \\
\text { (months) }\end{array}$ & \multicolumn{2}{|c|}{ Population studied } \\
\hline $\begin{array}{l}\text { Hillen ME at al, } \\
1994\end{array}$ & USA & $72 / 5$ & + & - \\
\hline $\begin{array}{l}\text { Steiger MJ et al, } \\
1996\end{array}$ & $\begin{array}{c}\text { England, } \\
\text { United Kingdom }\end{array}$ & $169 / 6$ & + & - \\
\hline $\begin{array}{l}\text { Cruz-Velarde JA et } \\
\text { al, } 2000\end{array}$ & Spain & $432 / 12$ & + & - \\
\hline $\begin{array}{l}\text { Costello D et al, } \\
2005\end{array}$ & Ireland & $577 / 12$ & + & - \\
\hline $\begin{array}{l}\text { Roberts K et al, } \\
2007\end{array}$ & Ireland & $254 / 6$ & + & - \\
\hline $\begin{array}{l}\text { Ali E et al, } \\
2010\end{array}$ & Ireland & $1016 / 12$ & + & + \\
\hline $\begin{array}{l}\text { Costelloe L et al, } \\
2011\end{array}$ & Ireland & $669 / 13$ & + & + \\
\hline $\begin{array}{l}\text { Douglas MR et al, } \\
2011\end{array}$ & $\begin{array}{c}\text { England, } \\
\text { United Kingdom }\end{array}$ & $120 / 3$ & + & - \\
\hline
\end{tabular}

+: yes; -: no; NA: data not available 
evaluation was scheduled in $28 \%$.

Considering the whole data, the neurologist's evaluation was considered to have an impact on the clinical management of $68 \%$ of inpatients.

\section{DISCUSSION AND CONCLUSION}

Some published studies have assessed the impact of the neurologist's work in a hospital setting, especially in the ED. However, very few studies have addressed the impact of the hospital neurologist on the evaluation of patients hospitalized under the supervision of other specialties, excluding the ED. ${ }^{1-8}$ Those particular studies (summarized in Table 3) were mainly performed in Ireland and the United Kingdom, countries where the number of neurologists per 100000 population is lower as compared to the rest of Europe. ${ }^{9}$ Comparisons between those studies must be made with caution, since sample population and background facilities substantially differ.

To the best of our knowledge, this is the first Portuguese study concerning this issue. In 2013, our department had a total of 17 doctors (nine residents and 14 consultants) who carried out inpatients consultations. On average, 24 consultations were performed each week. During weekends, urgent evaluations were also performed. Considering that each consultation takes around 45 minutes on average (including patient assessment and clinical record generation), this represents a significant workload.

Most patients needed special care for a medical or surgical reason and were correctly admitted by another specialty. Nevertheless, more than one-third of inpatients had a previous neurological diagnosis, reflecting the high prevalence and burden of neurological disorders. ${ }^{9}$ Those patients often experienced worsening of their symptoms during admission and neurology inpatient consultation allowed for a quick adjustment and return to baseline. Also, referrals were often intended for neurologic evaluation before or after sensitive medical procedures and recommendations on particular needs (i.e. adjusting sedative medication on demented old patients, transiently changing therapy based on medical status, neurologic

of other specialties
Main reasons for referral/diagnoses established
Time from referral to review

\section{Change or new diagnosis I management}

Referral to

Take over care neurology outpatient
Stroke $(27.8 \%)$, seizures $(20.8 \%)$, parkinsonism $(12.5 \%)$
NA

$43 \%$ considered useful
NA

NA

Cerebrovascular diseases (29\%), neuromuscular disorders (26\%), metabolic/toxic encephalopathy $(17 \%)$

NA

$33 \% / 31 \%$

NA

NA

\section{Cerebrovascular diseases (16\%), acute} metabolic encephalopathy (16\%)

Stroke $(22.7 \%)$, alcohol-unrelated seizures $(10.2 \%)$, alcohol-related neurological disorders $(9.5 \%)$

Seizures and loss of consciousness (28.3\%), sensori-motor complaints $(18.9 \%)$, stroke $(11.8 \%)$
All within $24-48 \mathrm{~h}$

$55.5 \% / 70 \%$

$6 \%$

$19,3 \%$
$3 \%$

$14 \%$

NA

$9 \%$
Seizures or "collapse" (28.3\%), stroke or TIA $(13.5 \%)$, headache $(12.5 \%)$
$77 \%$ within $24 \mathrm{~h}$

$-/ 72 \%$
$13 \%$

$2 \%$

Seizures diathesis $(20 \%)$, headache $(13 \%)$, cerebrovascular disorders (12\%)

$28 \%$ within $24 \mathrm{~h}$

$21 \% / 48 \%$

$19 \%$

NA

Cerebrovascular diseases $(24.2 \%)$, nonorganic $(17.5 \%)$, epilepsy $(11.7 \%)$

$70 \%$ within $24 \mathrm{~h}$

$52.5 \% / 41.7 \%$

NA

NA 
based assessment of contraindications, etc.). Some patients were diagnosed with a de novo neurological condition while admitted for another cause, which allowed treatment initiation and referral to the outpatient neurology clinic. We believe that this interdisciplinary cooperation has clear benefits for the patients.

Consultant neurologists examined almost one half of patients. Nevertheless, residents were involved in the majority of evaluations, which implies the subsequent need to discuss the clinical cases with a consultant. In fact, the knowledge of the particularities of patients in each department represents an excellent opportunity for residents to learn and build expertise. ${ }^{10}$ Evaluations were mostly carried out between 24 to 48 hours, which seems to be an appropriate response, suggesting the high quality standard of this work.

Cerebrovascular disease and epilepsy were the neurological diagnoses most frequently reported in our study, as well as in previously published works, with only slight variations concerning proportions. ${ }^{1-8}$ In our study, the diagnosis of stroke was established in $12 \%$ of cases and this might not represent misdiagnosis, as it is fairly common to evaluate strokes that occur after admission (i.e. complication of cardiothoracic surgery).

Cerebrovascular diseases and epilepsy are frequently managed by other medical specialties. However, the evaluation by a specialist in the field seems to be worthy and has an impact on patients' outcome. For instance, in a study by Kaste and Palomaki in a Finnish hospital, elderly patients with acute stroke were randomized to receive care in the departments of Medicine or Neurology. They found that patients treated in the Neurology department were discharged earlier and had better functional outcomes after one year of follow-up. ${ }^{11}$ As stated by Chadwick and Smith, seizures are also frequently misdiagnosed or over-treated prior to neurological evaluation. ${ }^{12}$

In our study, we found that the neurologist plays an important role assessing complications of systemic conditions, not only in medical and surgical departments but also in Intensive Care Units, which are very demanding: apart from diagnosis, management and neurological prognosis, they require a higher number of re-evaluations.

\section{REFERENCES}

1. Hillen ME, Sage JI. Proving the worth of neurologists? Neurology. 1996;46;276-.7.

2. Steiger MJ, Enevoldson TP, Hammans SR, Ginsberg L. Influence of obtaining a neurological opinion on the diagnosis and management of hospital inpatients. J Neurol Neurosurg Psychiatry. 1996;61:653-4.

3. Cruz-Velarde JA, Gil de Castro R, Vázquez PA, Ochoa MM. Study of inpatient consultation for the neurological services. Neurologia. 2000;15:199-202.

4. Costello D, Renhanathan R, O'Hare A, Murray B, Lynch T. Audit of an inpatient neurology consultation service in a tertiary referral centre: value of the consulting neurologist. Ir Med J. 2005;98:134-7.

5. Roberts K, Costelloe D, Hutchinson M, Tubridy N. What difference does a neurologist make in a general hospital? Estimating the impact of neurology consultations on in-patient care. Ir J Med Sci. 2007;176:2114 .

6. Ali E, Chaila E, Hutchinson M, Tudridy N. The 'hidden work' of a hospital
In a significant proportion of patients, the neurologist took an active role in management and/or diagnosis, changing patient care in $68 \%$ of cases. Different authors reported a significant impact as well. ${ }^{1-8}$ Others realized that after neurological evaluation, discharge was expedited in a significant percentage of patients (two-thirds to one half), resulting in major savings in resources..$^{5,7}$ These advantages are also highlighted by the 'neurohospitalist model', which advocates that the existence of neurologists especially dedicated to inpatients has economic and patient care benefits. ${ }^{13,14}$

The main limitations of our study are its retrospective nature, a possible selection bias, as only electronically registered consultations were analyzed, and the absence of long term follow-up that might attest to the positive impact of the intervention by the Neurologist.

Nevertheless, apart from allowing a clear picture of the inpatient consultation burden on our daily practice, this study led to a more effective re-organization of the clinical teams responsible for consultation to the different services, taking into account their particularities and requirements. Our findings suggest that our intervention is timely efficient and cost-effective. We believe it stamps high quality standards to inpatient care, and should be accounted for when designing hospital services and policies.

\section{PEOPLE AND ANIMALS PROTECTION}

The authors declare that the procedures were followed according to the regulations established by the Clinical Research and Ethics Committee and to the Helsinki Declaration of the World Medical Association.

\section{CONFIDENTIALITY OF DATA}

The authors declare having followed the protocols in use at their working center regarding patient's data publication.

\section{CONFLICTS OF INTEREST}

The authors declare they have no conflicts of interest.

\section{FUNDING SOURCES}

This research project was not funded by any public or private entity. neurologist: 1000 consults later. Eur J Neurol. 2010;17:e28-32.

7. Costelloe L, Rourke D, Monaghan TS, McCarthy A, McCormack R, Kinsella $\mathrm{J}$, et al. Liaison neurologists facilitate accurate neurological diagnosis and management, resulting in substantial savings in the cost of inpatient care. Ir J Med Sci. 2011;180:395-9.

8. Douglas MR, Peake D, Sturman SG, Sivaguru A, Clarcke CE, Nicholl DJ. The inpatient neurology consultation service: value and cost. Clin Med. 2011;11:215-1.

9. World Health Organization and the World Federation of Neurology. Atlas country resources for neurological resources - results of a collaborative study of the World Health Organization and the World Federation of Neurology. Geneva: WHO; 2004.

10. Probasco JC, George BP, Dorsey ER, Venkatesan A. Neurohospitalists: perceived need and training requirements in academic neurology. Neurohospitalist. 2014;4:9.

11. Kaste M, Palomaki H, Sarna S. Where and how should elderly stroke 
patients be treated? A randomized trial. Stroke. 1995;26:249-53.

12. Chadwick D, Smith D. The misdiagnosis of epilepsy. BMJ. 2002;324:4956.

13. Josephson A, Engstrom JW, Wachter RM. Neurohospitalists: an emerging model for inpatient neurological care. Ann Neurol. 2008;63:135S-40.

14. Barrett ML, Freeman WD. Emerging subspecialties in neurology: neurohospitalist. Neurology. 2010;74:e9-10. 